Jurnal Konstruksi Hukum | ISSN: 2746-5055

Vol. 2, No. 2, Mei 2021 Hal. 315-319| Tersedia online di

https://www.ejournal.warmadewa.ac.id/index.php/jukonhum

DOI: https://doi.org/10.22225/jkh.2.2.3229.315-319

\title{
MEKANISME PENYIMPANAN DAN PEMUSNAHAN BARANG SITAAN NARKOTIKA (STUDI KASUS PADA KEJAKSAAN NEGERI BADUNG)
}

\author{
I Putu Krisna Llham Wiantama, I Nyoman Gede Sugiartha, Ida Ayu Putu Widiati \\ Fakultas Hukum Universitas Warmadewa, Denpasar-Bali, Indonesia \\ putelsading@gmail.com, nyomansugiartha14@gmail.com, widiatidayu@yahoo.co.id
}

\begin{abstract}
Abstrak
Kasus tindak pidana Narkotika di wilayah hukum Kejari Badung tercatat banyak, prosedur penyimpanan benda sitaan Negara (Rupbasan) diatur dalam pasal 44 KUHAP, selanjutnya pemusnahan terhadap benda sitaan Narkotika dilaksanakan paling lama dalam jangka waktu tujuh hari setelah memperoleh utusan pengadilan yang memiliki kekuatan hukum tetap sebagaimana ketentuan Undang-Undang Nomor 35 Tahun 2009 tentang Narkotika. Namun implementasi dari undang-undang ini masih terlihat terkendala pelaksanaannya di lapangan. Penelitian ini bertujuan menjelaskan aturan hukum penyimpanan dan pemusnahan benda sitaan Narkotika pada Kejari Badung dan mendeskripsikan proses penyimpanan serta pemusnahan barang sitaan Narkotika di Kejari Badung. Penelitian ini didesain menggunakan metode normatif yaitu meneliti bahan pustaka dikaitkan dengan kasus melalui pendekatan perundang-undangan. Adapun data yang digunakan yaitu data primer dan sekunder. Data dikumpulkan dengan cara wawancara dan dokumentasi. Hasil penelitian menunjukkan aturan hukum penyimpanan benda sitaan Narkotika pada Kajari Badung, sesuai dalam Pasal 44 ayat (1) KUHAP, Perka BNN No. 7/2010, sedangkan untuk Pemusnahan diatur berdasarkan SE. I A Nomor: SE-018/ A/JA/08/2015 tanggal 21 Agustus 2015 adalah salah satu dasar hukumnya, selanjutnay mekanisme penyimpanan dan pemusnahan benda sitaan Narkotika diawali dari penerimaan pelimpahan wewenang dari penyidik kepadajaksa penuntut umum pada Kajari Badung dengan menghadirkan terdakwa dan barang bukti ke kantor Kejaksaan Negeri Badung. Jika proses persidangan telah selesai dan telah mempunyai kekuatan hukum retap, petugas memulai untuk mengumpulkan dan mendata berbagai benda sitaan yang akan dilakukan pemusnahan, dalam hal ini dibagi sesuai dengan jenis-jenis benda sitaan tersebut.
\end{abstract}

Kata Kunci: Narkotika, Kejaksaan, Pemusnahan, Pidana

\begin{abstract}
There are many criminal cases of Narcotics in the jurisdiction of the Badung Prosecutor's Office, the procedure for storing confiscated objects of the State (Rupbasan) is regulated in Article 44 of the Criminal Procedure Code, then the destruction of confiscated Narcotics is carried out seven days after obtaining a court envoy who has permanent legal force as provisions of Law number 35 of 2009 concerning Narcotics. However, the implementation of this law still appears to be constrained by its implementation in the field. This study aims to explain the legal rules for storing and destroying confiscated Narcotics at the Badung Public Prosecutor's Office and describing the process of storing and destroying confiscated Narcotics at the Badung District Court. This study was designed using a normative method, namely examining library materials in relation to cases through a statutory approach. The data used are primary and secondary data. Data were collected by interviewing and documentation. The results showed the legal rules for the storage of confiscated Narcotics at Kasiswa Badung, according to Article 44 paragraph (1) of the Criminal Procedure Code, Perka BNN No. 7/2010, while for Destruction is regulated based on SE.IA Number: SE-018 / A / JA / 08/2015 dated 21 August 2015 is one of the legal bases, then the mechanism for storing and destroying confiscated Narcotics objects begins with the acceptance of delegation of authority from investigators to the public prosecutor to District Prosecutor's Office Badung by presenting the defendant and evidence to the District Prosecutor's Office Badung Badung. If the trial process has been completed and has retained legal force, the officer begins to collect and record various confiscated objects that will be destroyed, in this case divided according to the types of confiscated objects.
\end{abstract}

Keywords: Narcotics, Attorney, Extermination, Criminal

\section{PENDAHULUAN}

Narkotika awalnya digunakan sebagai obat atau bahan yang dapat dimanfaatkan dibidang kesehatan serta pengembangan ilmu pengetahuan namun efek samping lainnya juga menyebabkan 
ketergantungan jika hal tersebut dipergunakan untuk hal yang salah dan menyimpang (Hariantika et al., 2016). Oleh sebab itu Pengendalian dan tindakan pengawasan yang semakin ketat dan secara saksama tentang tindakan memproduksi, menyimpan, mengimpor, mengekspor, mengedarkan atau menanam.

Menurut Pranomo, (2020) Menggunakan Narkotika tanpa pengendalian dan pengawasan yang ketat dan sangat seksama serta bertentangan dengan peraturan perundang-undangan merupakan tindak pidana Narkotika karena sangat merugikan, hali ini sangat membahayakan umat manusia untuk kelangsungan hidup yang lebih baik, untuk masyarakat, bangsa dan juga negara serta ketahanan nasional Indonesia. Semakin bertambahnya kasus penyalahgunaan narkotika tersebut, maka semakin bertambah juga barang sitaan narkotika yang disimpan dan dimusnahkan oleh Kejaksaan Negeri Badung. Hal ini membutuhkan penanganan yang lebih serius dari pada penyimpanan dan pemusnahan benda sitaan lainnya, sebagai dasar untuk menegakkan keadilan tersebut, diperlukan juga aturan hukum yang jelas tegas dan terperinci dalam hal untuk mengatasi masalah dan kendala yang dialami di lapangan sebagai penegak hukum. Kebanyakan kasus Narkotika adalah pemakai, hal ini sesuai dengan data yang dikumpulkan pada Kejaksaan Negeri Badung yang berjumlah 65 (enam puluh lima) kasus sejak awal 2019 sampai akhir 2020.

Dalam UU Narkotika disebutkan secara tegas dan jelas jika tindak pidana yang diatur di dalam UU Narkotika tersebut adalah kejahatan. Kejaksaan dalam melakukan mekanisme penyimpanan dan pemusnahan benda sitaan narkotika tersebut tetap berpedoman pada Pasal 44 KUHAP dan UU Nomor 35 /2009 tentang Narkotika, serta Peraturan Kepala BNN Nomor 7/ 2010.

Kejaksaan diberi wewenang oleh undang-undang untuk melakukan tugasnya di bidang yudikatif dengan dibuatnya undang undang Nomor 16/2004 tentang Kejaksaan. undang-undang ini mengatur tugas dari kejaksaan dalam menangani perkara. Jaksa selaku penuntut umum juga dikenal sebagai eksekutor, hal ini dikarenakan wewenang yang diberikan oleh undang-undang Kejaksaan untuk menjalankan putusan Hakim yang termasuk didalamnya berupa kewenangan terkait penyimpanan dan pemusnahan benda sitaan narkotika selama proses persidangan (Kadir \& Nufus, 2012). Untuk menunjang jaksa dalam melakukan penanganan perkara pidana narkotika, maka dari itu Kejaksaan Agung RI menerbitkan SE. IA Nomor Nomor: SE-018/A/JA/08/2015 tanggal 21 Agustus 2015. Dengan dasar tersebut, Jaksa pun memiliki otoritas terhadap benda sitaan yang akan disimpan dan dikelola di Rupbasan. Rupbasan adalah tempat dimana semua benda sitaan disimpan, namun jika tidak memungkinkan disimpan di Rupbasan, maka Jaksa menyimpan benda sitaan tersebut di ruang penyimpanan pada kantor Kejaksaan Negeri Badung sesuai dengan prosedur yang berlaku. Dalam prakteknya, jaksa selaku penuntut umum dipersidangan diberikan kewenangan untuk menuntut terdakwa dengan dihadirkan alat bukti, berupa barang bukti sitaan maupun keterangan saksi-saksi. Oleh sebab itu, diperlukan adanya akses yang mud ah oleh jaksa.

Benda yang disita tersebut dilarang untuk diedarkan, kemudian dirampas untuk dipergunakan bagi kepentingan negara atau untuk dimusnahkan". Pasal 2 Ayat (I) UU No. 16/2004 tentang Kejaksaan RI, dikatakan "Kejaksaan RI yang selanjutnya dalam UU ini disebutkan Kejaksaan RI merupakan lembaga pemerintahan yang melaksanakan kekuasaan negara dalam bidang penuntutan dan kewenangan lainnya menurut UU. Benda yang disita tersebut masih memiliki potensi untuk terjadinya banyak penyimpangan maupun tindak pidana yang tidak diinginkan di dalam pelaksanaannya ataupun pengawasannya, oleh karena itu dikhawatirkan masih ada kemungkinan benda yang telah disita tersebut akan beredar dan dijual kembali di tengah masyarakat. Walaupun didalam aturannya, barang yang disita tersebut harus dilakukan pemusnahan dan harus benar-benar dimusnahkan dalam waktu 7 (rujuh) hari setelah benda yang disita tersebut telah mempunyai kekuatan hukum tetap sesuai surat keputusan dari pengadilan negeri.

Ada beberapa penelitian terdahulu terkait penelitian ini yaitu (Mawar \& Rizal, 2019); (Rujianto \& Astuti, 2020) Mengugkapkan mekanisme pelaksanaan pemusnahan barang sitaan narkotika harus mengikuti sesuai prosedur yang telah dimuat dalam undang-undang, jika kelihatan ada anggota kejaksaan atau penyidik yang melakukan pemusnahan yang tidak mengikut prosedur undang-undang akan diberi sanksi hukum secara tegas. Walaupun sudah banyak penelitian terdahulu terkait penelitian ini, masalah penggunaan Narkoba masih terjadi sampai saat ini, berdasarkan hal ini peneliti mencoba melakukan penelitian tentag masalah ini dengan cara penyajian data yang berbeda. Penelitian ini bertujuan menjelaskan aturan hukum penyimpanan dan pemusnahan benda sitaan Narkotika pada 
Kejari Badung dan mendeskripsikan proses penyimpanan serta pemusnahan barang sitaan Narkotika di Kejari Badung

\section{METODE PENELITIAN}

Penelitian ini didesain menggunakan penelitian hukum normatif yaitu metode atau cara yang dipergunakan dalam penelitian hukum yang dilakukan dengan cara meneliti bahan pustaka yang ada dikaitkan dengan masalah yang sedang diteliti (Mukti Fajar ND, 2013). Penedekatan yang diterapkan adalah pendekatan perundang-undangan untuk melakukan penelusuran bahan-bahan hukum dalam pendekatan masalahnya. Adapun data yang digunakan adalah bersumber dari data hukum primer dan sekunder. Data primer dioeroleh dengan cara membaca dan menganalisis peraturan perundangundangan, buku-buku, artikel dan bahan lain yang berkaitan dengan penelitian ini. Data dikumpulkn dengan metode wawancara dengan responden dan informan yang bersal dari instansi yang berwenang.

\section{HASIL DAN PEMBAHASAN}

\section{Pengaturan Penyimpanan dan Pemusnahan Benda Sitaan Narkotika pada Kejaksaan Negeri Badung}

Obat adalah sesuatu atau benda yang dibuat oleh manusia dan diciptakan untuk memenuhi kebutuhan atau keperluan sesorang, obat yang dapat menenangkan saraf adalah salah satu obat yang paling banyak diproduksi, kemudian obat penghilang rasa sakit yang digunakan untuk menghilangkan rasa sakit,efek lainnya obat tersebut dapat menimbulkan rasa ngantuk setelah dikonsumsi dan efek lainnya juga buruk. Menurut Mardani, (2008) Penggunaan obat yang tidak sesuai dosis ataupun resep dokter juga diartikan sebagai Narkotika. Ada beberapa golongan narkotiak yaitu Narkotika golongan satu (terdiri dari 65 zat), narkotika golongan dua (terdiri dari 86 zat), narkotika golongan tiga (terdiri dari 14 zat). Benda sitaan kemudian disimpan didalam rumah penyimpanan untuk benda sitaan Negara dan tanggung jawabnya ada pada pejabat yang berwenang sesuai tingkat pemeriksaan di dalam proses peradilan. Penyitaan tersebut merniliki dua bentuk perbuatan, salah satunya yaitu rnengambil alih dan menyimpan di bawah penguasaan.

Untuk kepentingan pembuktian perkara yang menjadi tujuan penyitaan, Penyidik juga harus memahami konsep kepemilikan sebuah benda. Benda sitaan disimpan dalam Rupbasan. (Siswanto, 2012). Pemusnahan dalam hukum pidana memiliki definisi sebagai proses penghancuran BB dilakukan oleh eksekutor sesuai prosedur yang berlaku yang diatur dalam UU. Untuk pemusnahan Narkotika, pelaksanaannya dilakukan jika ada penetapan dari Kajari setempat kemudian disaksikan oleh pejabat yang mewakili unsur Kejaksaan, Kepolisian, BNN, Kementerian Kesehatan dan BPOM.

Berdasrakan pasal 54 ayat (1) UU No. 48/2009 tentang Kekuasaan Kehakiman, menyebutkan jika, pelaksanaan putusan pengadilan dalam perkara pidana dilakukan oleh jaksa (Hamzah, 2014). Eksekutor dalam kamus besar bahasa Indonesia adalah orang yang melaksanakan eksekusi. Selain sebagai penuntut umum, jaksa dalam melaksanakan tugasnya juga disebut sebagai eksekutor terhadap putusan pengadilan yang telah memiliki kekuatan hukum tetap oleh Pengadilan Negeri (Makarao, 2003). Sebagai eksekutor yang melakukan dan melaksanakan penetapan hakim dan putusan pengadilan yang telah mempunyai kekuatan hukum tetap (Tumpa, 2011). Barang sitaan narkotika dan prekursor narkotika yang berada dalam penyimpanan dan pengamanan penyidik yang telah ditetapkan untuk dimusnahkan, wajib dimusnahkan dalam waktu paling lama 7 (tujuh) hari terhitung sejak menerima penetapan pemusnahan dari Kepala Kejaksaan Negeri setempat.

\section{Proses Penyimpanan dan Pemusnahan Benda Sitaan Narkotika di Kejaksaan Negeri Badung}

Sebagai lembaga pemerintah yang diberikan kewenangan dalam melaksanakan kekuasaan Negara di bidang penuntutan serta kewenangan lain berdasarkan UU, dalam menentukan apakah suatu perkara tersebut bisa dinaikan ketahap penuntutan di Pengadilan Negeri setempat, Jaksa mempunyai kewenangan dalam hal tersebut. Hal ini dikarenakan berdasarkan kecukupan alat bukti yang mendukung dan yang sah menurut Hukum Acara Pidana.

Bidang pidana Umum dan Khusus mempunyai tugas untuk melakukan proses penuntutan perkara atas surat perintah, melaksanakan penetapan putusan hakim yang diterima oleh jaksa sesuai dengan putusan pengadilan yang akan ditindak lanjuti untuk dilaksanakan sesuai dengan surat perintah dari Kajari yang berdasarkan surat purusan pengadilan, kemudian dilakukan pengawasan dalam hal dilaksanakannya putusan pidana tertentu sesuai dengan UU yang berlaku serta yang telah 
mempunyai kekuatan hukum tetap, melengkapi berkas perkara tertentu agar dapat dilakukan pelimpahan perkara ke Pengadilan dan segera diadili sesuai ketentuan UU yang berlaku, sampai perkara tersebut inkracht (mempunyai kekuatan hukum tetap untuk dilakukan eksekusi oleh eksekutor yang tidak lain adalah Jaksa yang menangani perkara tersebut). Sebagai seorang JPU (Jaksa Penuntut Umum) yang diberikan mandat dan tugas oleh undang-undang, sudah seharusnya bersikap dan selalu mengutamakan keadilan dengan menggunakan hati Nurani sebagai dasar dalam mengambil keputusan, karena dalam menangani masalah atau perkara, tidak boleh dilakukan secara berat sebelah, akan tetapi harus dilakukan secara adil dan bijaksana.

JPU mempunyai kewenangan terhadap benda sitaan, memiliki kewenangan juga unruk mengeluarkan dan mengembalikan barang bukti yang disimpan di ruang penyimpanan khusus baik di Kajari maupun di Rupbasan sesuai dengan surat perintah dan ketetapan dari Pengadilan yang mengadili perkara tersebut. Kewenangan ini diberikan kepada JPU sampai BB tersebut dikembalikan di ruang penyimpanan kembali. Barang bukti sitaan disimpan di ruangan khusus penyimpanan di kantor Kajari Badung memang tidak sesuai dengan aturan perundang undangan yang berlaku, karena jika sesuai aturannya harus disimpan di Rupbasan, hal tersebut disebabkan karena efektifitas JPU dalam melakukan persidangan jika dibandingkan disimpan di Rupbasan, menyimpan di Kajari lebih efektif karena jaksa yang akan sidang ke PN Denpasar bisa berangkat dari kantor dan mengambil barang bukti yang akan diperlukan dalam persidangan dengan menunjukan surat permintaan pengeluaran barang bukti kepada petugas penyimpan barang bukti di Kajari Badung, dari barang bukti yang dikeluarkan untuk persidangan sampai barang bukti tersebut kembali disimpan di ruang penyimpanan barang sitaan Narkotika.

Khusus untuk barang bukti Narkotika, penyimpanannya sedikit berbeda dengan barang benda biasa pada umumnya, barang benda Narkotika disimpan terpisah (jika di Kajari badung, disimpan di ruangan khusus yang memiliki trali dan disimpan di dalam Brankas besi) dari barang bukti lainnya. Mekanismenyapun berbeda antara pemusnahan. Umurnnya, pada awal Kajari Badung menerima surat pemberitahuan penyitaan barang bukti narkotika dari penyidik, Kajari harus mengeluarkan surat penetapan apakah barang bukti tersebut akan dipergunakan untuk keperluan pembuktian perkara dalam perkara lainnya, selama kurun waktu 7 (tujuh) hari setelah Kejari menerima Surat Pemberitahuan dan jika menyangkut kepentingan pengembangan dan proses penelitian untuk pengetahuan maka hal pemusnahan dapat ditoleransi.

Dalam prakteknya berbeda dari aturan yang berlaku, barang bukti yang telah memiliki kekuatan hukum tetap tersebut tidak langsung dimusnahkan sesuai dengan batas waktu 7 (tujuh) hari yang telah ditetapkan, dikarenakan terdapat banyaknya hambatan sehingga pemusnahan tersebut tidak bisa langsung dilaksanakan sesuai dengan batas waktu yang diberikan. Kejari Badung rnelalui ketetapan Kajari Badung menetapkan bahwa barang bukti narkotika harus dimusnahkan paling lama 3 (tiga) bulan setelah mempunyai kekuatan hukum tetap. Kajari Badung sudah menangani 65 kasus narkotika dari awal Januari 2019 sampai akhir tahun 2020. Kejaksaan selalu mengalami hambatan dan kendalakendala sehingga pelaksanaan tugasnya di lapangan dapat berbeda dengan yang ditetapkan UndangUndang. Hal ini terjadi faktor penyimpanan dan pemusnahan yang dihadapi.

Kajari Badung secara khusus sudah melakukan berbagai macam upaya demi mengatasi kendala yang dihadapi oleh Kejari Badung yaitu saling berkoordinasi dengan Kejati Bali untuk rmencari solusi atas kendala yang dihadapi baik yang menyangkut Proses Penyimpanan dan Pemusnahan Benda yang disita yang sudah memiliki kekuatan hukum tetap (tidak menjadi alat bukti dalam perkara lainnya). Proses penyimpanan di Kajari Badung mendapat penyelesaian yang saling menguntungkan antara aturan dan yang melaksanakannya, dalam hal ini jaksa dan petugas penyimpanan agar tidak diberi sanksi ketika masih menyimpan benda sitaan narkotika di kejaksaan Negeri Badung selama tidak ada penyelewengan terhadap benda sitaan narkotika tersebut. Dalam prosesnya, petugas barang bukti Kejari Badung secara tegas dan bijaksana dan bertanggungjawab penuh atas pengadministrasian serta pencatatan secara rutin dan tepat sesuai keadaan yang diterima tanpa mengurangi ataupun menambahkan. Hal ini juga berguna agar perkara yang disidangkan mendapatkan putusan seadiladilnya tanpa ada pihak manapun yang dirugikan akan hal tersebut. Kemudian hal lain yang dilakukan oleh Kejaksaan Negeri Badung adalah pengusulan anggaran biaya tambahan kepada Kajari Badung oleh pemerintah untuk pemusnahan agar dibiayai sesuai dengan ketentuan UU yang berlaku. Tahap terakhir adalah melakukan Evaluasi kendala-kendala yang dihadapi di lapangan yang bisa bertambah kapan saja sesuai dengan perkembangan zaman dan teknologi. 


\section{SIMPULAN DAN SARAN}

\section{Simpulan}

Dari bahasan dan hasil analisis data dapat disimpulan bahwa aturan hukum penyimpanan benda sitaan Narkotika pada Kajari Badung, sesuai dengan bunyi dalam Pasal 44 Ayat (1) KUHAP, Perka BNN No. 7/2010, sedangkan untuk Pemusnahan Benda Sitaan Narkotika diatur berdasarkan SE.I A Nomor: SE-018/ A/JA/08/2015 tanggal 21 Agustus 2015 adalah salah satu dasar hukumnya. Pengeluaran benda sitaan sesuai pasal 45 ayat (I) KUHAP dan petunjuk pelaksanaan angka 2 Lampiran Keputusan Menteri Kehakiman o. M .14-PW .07 .03/1983. Mekanisme penyimpanan dan pemusnahan benda sitaan Narkotika diawali dari penerimaan pelimpahan wewenang dari penyidik kepadajaksa penuntut umum pada Kajari Badung dengan menghadirkan terdakwa dan barang bukti ke kantor Kajari Badung. Setelah berkas lengkap, lalu dibuatkan berita acara untuk menerima terdakwa dan barang bukti. Jaksa yang menangani perkara tersebut menerima barang bukti tersebut, diberikan kepada petugas untuk disimpan dalam ruang barang bukti. Jika proses persidangan telah selesai dan telah mempunyai kekuatan hukum retap, petugas memulai untuk mengumpulkan dan mendata berbagai benda sitaan yang akan dilakukan pemusnahan, dalam hal ini dibagi sesuai dengan jenis-jenis benda sitaan tersebut, baik secara ukuran ataupun secara berat dan volumenya, setelah hal tersebut selesai barulah dilakukan pemusnahan barang bukti narkotika.

\section{Saran}

Dari hasil penelitian, adapun saran yang dapat disampaikan adalah kepada pihak Kejari Badung agar menjalankan penyimpanan dan pemusnahan benda sitaan narkotika tersebut adalah benda sitaan sebaiknya disimpan di tempat yang sudah ditetapkan oleh undang-undang yaitu di Rupbasan, karena di wilayah hukum Kabupaten Badung belum mempunyai Rupbasan sendiri, hal ini dapat diatasi dengan dititipkan di Rupbasan Denpasar, karena belum ada Rupbasan Badung. Diharapkan Pemerintah agar memberikan anggaran biaya terhadap Pemusnahan sesuai dengan aturan yang berlaku dan yang terjadi dilapangan. Kepada Kejari Badung juga sebaiknya bersurat kepada Kejaksaan Agung RI agar tata cara pemusnahan benda sitaan Narkotika dibuatkan aturan khusus lengkap dengan tata cam pemusnahannya agar penegakan hukum tetap maksimal dilakukan tanpa ada pihak yang dirugikan.

\section{DAFTAR PUSTAKA}

Hamzah, A. (2014). Hukum Acara Pidana Indonesia. Jakarta: Sinar Grafika.

Hariantika, R. D., Sukinta, \& Baskoro, B. D. (2016). Proses Pemusnahan Barang Bukti Narkoba Sebelum Putusan Hakim di Wilayah Hukum Polretbes Semarang. Jurnal Law, 5(4), 1-20.

Kadir, N. A., \& Nufus, C. (2012). Perlindungan Benda Sitaan Negara dan Barang Rampasan dalam Proses Peradilan Pidana. Lex Jurnalica, 9(1), 31-43.

Makarao, M. T. (2003). Tindak Pidana Narkotika. Jakarta: Ghalia Indonesia.

Mardani. (2008). Penyalahgunaan Narkoba dalam Perspektif Hukum Islam dan Hukum Pidana Nasiona. Jakarta: Raja Grafindo Persada.

Mawar, S., \& Rizal, S. (2019). Mekanisme Penyimpanan dan Pemusnahan Benda Sitaan Narkotika (Studi Kasus pada Kejaksaan Tinggi Aceh). Jurnal Justisia, 4(1), 1-22.

Mukti Fajar ND, Y. A. (2013). Dualisme Penelitian Hukum Normatif dan Hukum Empiris. Yogyakarta: Pustka Pelajar.

Pranomo, A. (2020). Putusan Hakim terhadap Barang Bukti Narkotika Dirampas untuk Negara. Jurrnal Pancasila And Law Review, 1(1), 19-34.

Rujianto, V. A. P., \& Astuti, P. (2020). Pelaksanaan Pemusnahan Barang Sitaan Narkotika di Kabupaten Lamongan. Jurnal Hukum, 2(4), 1-23.

Siswanto, S. (2012). Politik Hukum dalam Undang-Undang Narkotika. Jakarta: Rineka Cipta.

Tumpa, H. H. A. (2011). Komentar \& Pembahasan Undang-Undang Nomor 35 Tahun 2009 tentang Norkotika. Jakarta: Sinar Grafika. 